\title{
EFFECT OF MICROFINANCE ADOPTION ON RURAL HOUSEHOLD INCOME IN SELECTED UPAZILA OF KUSHTIA DISTRICT OF BANGLADESH
}

\author{
Bilkish Banu \\ Assistant Professor \\ Department of Economics \\ Hajee Mohammad Danesh Science \& Technology University \\ Dinajpur-5200, Bangladesh \\ E-mail: bilkishbanuu@gmail.com \\ Mohammad Mukul Hossain \\ MBA Student \\ Department of Management Studies \\ University of Rajshahi, Bangladesh \\ E-mail: mukul101ru@gmail.com \\ Mohammad Samiul Haque \\ MBA Student \\ Department of Finance and Banking \\ Hajee Mohammad Danesh Science \& Technology University \\ Dinajpur-5200, Bangladesh \\ E-mail: samiulhaque445@gmail.com \\ Babor Ahmad \\ MSS Student \\ Department of Economics \\ Hajee Mohammad Danesh Science \& Technology University \\ Dinajpur-5200, Bangladesh \\ E-mail: baboraswapon@gmail.com
}

\begin{abstract}
This present study aims at analyzing how microfinance affects household income of its participants as well as to find out the factors that influence the participants to adopt loan for which a logit model was applied. This study was run on three villages of Daulatpur Upazila of Kushtia district namely Khalishakundi, Malipara and Silimpur from which 350 respondents were chosen randomly. The result reveals that Age $(p<0.05)$, household size $(p<0.01)$ and credit amount $(p<0.05)$ from microfinance had significant negative impact on average household income and spouse's income had a positive sign with coefficient of 0.867 which was significant $(p<0.01)$. Logit model expresses that average income, age of respondent and household size all had negative sign implying that an increase of one of them will discourage the respondents tending towards borrowing loans from microfinance which were also significant $(p<0.01)$. This study also found several problems faced by the participants of microfinance such as high interest rate, delay of credit, rude behavior of representatives, short recovery time, influence of old members etc. as well as recommend the policy implication regarding them.
\end{abstract}


Keywords: Microfinance, Household Income, Credit, Logit Model, Policy Implication.

JEL Classification Codes: G21, Q52, O18, D13

\section{INTRODUCTION}

Microfinance is the provision of savings, credit, deposit, insurance and repayment services to the low-income households to enable them to create employment opportunities and reduce poverty by starting their own businesses and thus generating income. In Bangladesh there are mainly four types of institutions involved in microfinance activities. These are Grameen Bank (GB), around 1500 non-government organizations (NGO), commercial and specialized banks like Bangladesh Krishi Bank (BKB), Rajshahi Krishi Unnayan Bank (RAKUB), and government-sponsored microfinance projects (Bangladesh Bank). The NGOs started credit programme in the mid-1980s and their activities increased noticeably after 1990. With the increasing number of collateral-free micro credit disbursement by the MFIs, some nationalized commercial banks (NCBs), and specialized banks were encouraged to provide a considerable amount of their rural credit to the poor without security. Today, some of the private commercial banks (PCBs) have also started direct and linkage programmes with the NGOs. Microfinance provides households with loan to group of borrowers with peer monitoring to secure loan for exchange of physical collateral. Lowincome households take loan for accumulation assets, emigration assets, emigration to abroad, small business, cultivation, reinvestment, betroth, education for children, dowry, smooth consumption, land purchase, health and housing, women empowerment and employment opportunities for the borrowers households. Microfinance improves the standard of living of the poor by creating income and employment opportunities. Microfinance gives not only loan but also training and social activities to the household for support self-employment and small business. However, transformation of the MFIs was inevitable considering rural economic growth and financial inclusion requirements of Bangladesh where some 50 per cent of the adult population remain unbanked. Microcredit Regularity Authority' (MRA) was formed in 2006 to ensure transparency in activities of the micro-lending institutions. The high interest rates of microcredit were widely criticised at home and abroad. The government fixed the interest ceiling at 27 per cent in 2010. It was said that gradually the rates would be reduced further, but nothing has been done about this over the last one decade. The government has recently decided to slash down interest rates on microcredit provided by the NGOs by 3.0 per cent in order to attain the Sustainable Development Goals (SDGs). The finance ministry approved the interest rates at 24 per cent after the authorities introduced the recommendation. Overall, Microfinance increases household income and the standard of living of the poor households (The Financial express).

The study found out that the microcredit programmes of ASA helps both rural and urban poor households to improve their standard of living by increasing income, expenditures, saving and poverty reduction. Besides, the microcredit institutions gain competitive advantage by providing both micro financing and other various services such as education, skill-based programmes, and training sessions (Ariful et al., 2017). MFI loans impact on both household income and food consumption. A productive loan reduces the income poverty trends of households and non-productive loans minimize consumption poverty and BMI (Imai \& Azam, 2012). Microfinance access improves the consumption, household income and poverty status but microfinance members take loans to smooth consumption rather than investing in petty business (Bhuiya et al., 2016). Microfinance has a significant positive impact on increasing household income label and reducing widespread poverty from the rural areas of Bangladesh and age, family member and loan amount role in household income determination (Basu et al., 2020). The 
microfinance of BRAC has diverted borrowers (93\% of respondents) to self-employed activities which develop high income and the contribution to the family expenditure and $7 \%$ of respondents have employed in low paid works after joining. (Hossain, 2012). Despite higher loans to cumulative borrowing microfinance continues to reduce poverty among poor borrowers and increase per capita household consumption within the local economy for participation and non-participants (Khandker, 2005). A utilized extensive microfinance operation helps increasing informal employment and achieving goals of poverty reduction as well as leading of greater economic development (Shahnaz et al., 2018). Microfinance empower the poor, reduces catastrophic income loss and poverty, increase employment by diversifying their income source (Wright, 1999). Microcredit mostly impresses the poor for poverty reduction, savings, microfinance and training in Bangladesh (Chowdhury et al., 2020). Microfinance increases household income after persistence, participation in the programmes. All households both participants and non-participants of microfinance registered increases in household welfare (Islam, 2016). The age, monthly income, of borrowers, interest rate and loan duration help the credit accessibility of rural households in Bantul. Borrower's income, total household assets and changes in expenditure measure the assessment relates to the credit impacts. Microfinance reduces poverty and increases consumption but microcredit borrowers have higher consumption than non-borrowers, besides microfinance influences the standard of living and property level.

\section{MATERIALS AND METHODS}

This present study used data collected from three villages of Daulatpur Upazila in Kushtia district namely Khalishakundi, Malipara and Silimpur. The questionnaire was prepared in English and filled up with face to face interview and collected from September 2020 to December 2020. The study considered each household as the unit of analysis for evaluating the effect of microfinance on household income (Zewde \& Tollens, 2008; Panda \& Atibuddi, 2010). Following Panda and Atibuddi (2010) two group was made one is treatment group indicating those who adopted microfinance as beneficiary households from undertaking microfinance (more than two years till this survey) and the second is controlled group indicating those who are new entrants in microfinance programme and did not receive any loan (Kondo et al., 2008 \& AlAzzam, 2006). To analyze the effect of microfinance the multivariate regression model with double logs was used as below.

$$
\ln Y_{i}=\ln \alpha_{0}+\ln \beta_{1} X_{1 i}+\ln \beta_{2} X_{2 i}+\ln \beta_{3} X_{3 i}+\ln \beta_{4} X_{4 i}+\ln \beta_{5} X_{5 i}+\ln \beta_{6} X_{6 i}+\ln \beta_{7} X_{7 i}+\varepsilon_{i}
$$

Where,

$\ln =$ Natural logarithm;

$\mathrm{Y}=$ Monthly average income measured in taka;

$\mathrm{X}_{1}=$ Age of the respondent measured in years;

$\mathrm{X}_{2}=$ Adoption of microfinance loan by participant measured by dummy variable as 1 for adopt loan and 0 for otherwise;

$\mathrm{X}_{3}=$ Education level of participant measured by years of schooling;

$\mathrm{X}_{4}=$ Size of household measured in numbers; 
$\mathrm{X}_{5}=$ Spouse's income (monthly) measured in taka;

$\mathrm{X}_{6}=$ Amount of credit measured in taka;

$\mathrm{X}_{7}=$ Agricultural holdings measured in hectare .

$\alpha$ and $\beta$ 's are the unknown parameters to be estimated, $\varepsilon$ refers to error term and $\mathrm{i}$ indicates $1,2,3, \ldots \ldots, \mathrm{n}$.

There are several factors influencing the farmers to participate microfinance that were analyzed with limited variable model namely logit model.

$$
\mathrm{L}_{\mathrm{i}}=\ln \left(\frac{\mathrm{P}_{\mathrm{i}}}{1-\mathrm{P}_{\mathrm{i}}}\right)=\mathrm{Z}_{\mathrm{i}}=\beta_{1}+\beta_{2} \mathrm{X}_{2}+\ldots \ldots \ldots+\beta_{\mathrm{n}} \mathrm{X}_{\mathrm{n}}
$$

Here, $\frac{P_{i}}{1-P_{i}}$ is the odd ratio in favor of occurring an event (Gujarati, 2009).

Then for our study,

$L_{i}=\ln \left(\frac{P_{i}}{1-P_{i}}\right)=\ln \beta_{0}+\beta_{1} \ln X_{1 i}+\beta_{2} \ln X_{2 i}+\beta_{3} \ln X_{3 i}+\beta_{4} \ln X_{4 i}+\beta_{5} \ln X_{5 i}+\beta_{6} \ln X_{6 i}+u_{i}$

Where,

$\frac{P_{i}}{1-P_{i}}$ is the odd ratio in favor of adopting loan from microfinance by the respondent measured by 1 for took a loan and 0 for otherwise. $X_{1}=$ Average income of household measured in taka; $X_{2}=$ Age of respondent measured in years; $X_{3}=$ Educational level of the respondent measured by years of schooling; $\mathrm{X}_{4}=$ Household size measured in numbers; $\mathrm{X}_{5}=$ Land holdings by respondent measured in hectare; $\mathrm{X}_{6}=$ Availability of credit taken as dummies measured by 1 for easier to grant a loan compared to banks and 0 for otherwise. $u$ was the stochastic disturbance term including all other factors that may affect the model and in equation (5), i represented number as $1,2,3, \ldots, \mathrm{n}$.

Pseudo $\mathrm{R}^{2}$ (McFadden's) was computed as

$$
\mathrm{R}^{2}=1-\frac{\hat{L}\left(M_{\text {full }}\right)}{\widehat{L}\left(M_{\text {Intercept }}\right)}
$$

Where,

$\left(M_{\text {full }}\right)=$ Model with predictors; $\left(M_{\text {Intercept }}\right)=$ Model without predictors and $\hat{L}=$ Estimated likelihood. This represents the strength of the offered model. The higher the value of Pseudo $\mathrm{R}^{2}$, the more fitted model is.

\section{RESULT AND DISCUSSION}

\section{Effect of Participation in Microfinance on income}

Participation in the microfinance has a great impact on the household income shown in table 2 by comparison of average income between control and treatment group where the average income of control group is higher than that of the treatment group indicated by the mean difference of 2161.50 which was statistically significant $(\mathrm{p}<0.01)$ recorded by $t$ ratio of 4.786 . This result was 
similar with the findings of Jasmine (2008); Panda and Atibudhi (2010); Kundu, (2012); Sharma (2008); and Sarania (2015).

Table 1. Descriptive Statistics $(\mathrm{N}=350)$

\begin{tabular}{|c|c|c|c|c|c|}
\hline Variables & Measurement & Mean & Std. Dev. & Min. & Max. \\
\hline Marital status & $\begin{array}{l}\text { Measured in three points; } 1 \\
\text { for single, } 2 \text { for married and } 3 \\
\text { for widow }\end{array}$ & 2.022 & 0.149 & 2 & 2 \\
\hline Age & Measured in years & 32.442 & 8.599 & 18 & 56 \\
\hline Educational level & Years of education & 5.845 & 3.465 & 0 & 12 \\
\hline Family size & Numbers of persons & 3.605 & 1.042 & 1 & 6 \\
\hline Average income & Taka (Monthly) & 5675.262 & 3155.258 & 1000 & 43333.33 \\
\hline Spouse income & Taka (Monthly) & 19612 & 10682.38 & 5000 & 130000 \\
\hline Land holdings & Hectare & 0.135 & 0.216 & .01 & 1.32 \\
\hline $\begin{array}{l}\text { Membership of } \\
\text { Microfinance }\end{array}$ & Measured in Months & 68.240 & 60.255 & .12 & 360 \\
\hline loan & $\begin{array}{l}\text { Dummy variables as } 1 \text { for } \\
\text { took load and } 0 \text { for otherwise }\end{array}$ & 0.282 & 0.451 & 0 & 1 \\
\hline Loan amount & Taka & 39934.29 & 32774.56 & 3000 & 200000 \\
\hline Loan availability & $\begin{array}{l}\text { Dummy variables as } 1 \text { for } \\
\text { easier compared to } \\
\text { Government and Private } \\
\text { banks and } 0 \text { for otherwise }\end{array}$ & 0.888 & 0.315 & 0 & 1 \\
\hline Interest rate & $\begin{array}{l}\text { Dummy variables as } 1 \text { for } \\
\text { lower compared to } \\
\text { Government and Private } \\
\text { banks and } 0 \text { for otherwise }\end{array}$ & 0.034 & 0.182 & 0 & 1 \\
\hline
\end{tabular}

Source: Authors' own computation from survey data of 2020

Table 2. Comparison of average income (monthly) between control and treatment group

\begin{tabular}{|l|l|l|l|l|}
\hline Variable & Treatment group & Control group & Mean differences & t- ratio \\
\hline Average income & 6527.50 & 4366.00 & $2161.5^{* * *}$ & 4.786 \\
\hline Standard deviation & 4222.961 & 2052.52 & & \\
\hline $\begin{array}{l}\text { Standard Errors } \\
\text { differences }\end{array}$ & \multicolumn{4}{|c|}{$451.586^{* * *}$} \\
\hline
\end{tabular}

*** Refers to $1 \%$ level of significance.

Table 3 represents how much income of household was affected by microfinance participation analyzing with Ordinary Least Squares (OLS) where average income was positively affected having significant at 5\% level with catirus paribus that is if all the other factors were held constant. Age, household size and credit amount all had significant negative impact on average income implying that an increase of one of them will reduce the average income of the 
household and vice versa where household size was significant at $1 \%$ level and the rests were at $5 \%$ level. On the contrary spouse's income had a positive sign with coefficient of 0.867 indicating an $1 \%$ increase of spouse's income will raise the average family income by $86.7 \%$ which was significant $(\mathrm{p}<0.01)$.

Table 3. Effect of microfinance participation on the household income $(\mathrm{N}=350)$

\begin{tabular}{|l|l|l|l|l|}
\hline Variables & Parameters & Coefficients & $\begin{array}{l}\text { Standard } \\
\text { Errors }\end{array}$ & t- ratios \\
\hline Constant & $\alpha_{0}$ & $2.516^{* *}$ & 1.026 & 2.45 \\
\hline Age of respondent & $\beta_{1}$ & $-0.332^{* *}$ & 0.159 & -2.09 \\
\hline Education level & $\beta_{2}$ & 0.054 & 0.049 & 1.11 \\
\hline Size of household & $\beta_{3}$ & $-0.912^{* * *}$ & 0.095 & -9.58 \\
\hline Spouse's income & $\beta_{4}$ & $0.867 * *$ & 0.071 & 12.16 \\
\hline Amount of credit & $\beta_{5}$ & $-0.022^{* *}$ & 0.009 & -2.40 \\
\hline Agricultural holdings & $\beta_{6}$ & -0.004 & 0.026 & -0.16 \\
\hline F & $100.18^{* * *}$ & & \\
\hline R-squared & 0.320 & & \\
\hline Number of Observations & 350 & & \\
\hline
\end{tabular}

Note: $*, * *$ and $* * *$ Asterisks refer $1 \%, 5 \%$ and $10 \%$ level of significance respectively.

\section{Factors influencing participants to adopt loan}

Table 4 shows the determinants of adopting microfinance loan by its participants. Pseudo $\mathrm{R}^{2}$ represents how the model is fitted similarly as of $\mathrm{R}^{2}$ in case of OLS. LR chi ${ }^{2}$ of 108.06 shows that the model is statistically significant $(\mathrm{p}<0.01)$. The result reveals that 242.9 percent loan adoption rises with catirus paribus at $1 \%$ level of significance. It is also seen that the average income, age of respondent and household size all had coefficient with negative sign implying that an increase of one of them will discourage the respondents tending towards borrowing loans from microfinance and all of them were significant at $1 \%$ level. The other factors such as educational level, land holding and availability of credit were not significant.

Table 4. Factors affecting participants in adopting loan

\begin{tabular}{|l|l|l|l|}
\hline Variables & Coefficients & $\begin{array}{l}\text { Standard } \\
\text { Errors }\end{array}$ & Z- Statistics \\
\hline Constant & $24.296^{* * *}$ & 4.028 & 6.03 \\
\hline Average income (Tk./Monthly) & $-1.774 * * *$ & 0.311 & -5.69 \\
\hline Age of respondent (Years) & $-2.005 * * *$ & 0.744 & -2.69 \\
\hline Educational level (Years of schooling) & -0.110 & 0.244 & -0.45 \\
\hline Household size (No.) & $-2.776^{* * *}$ & 0.5004 & -5.55 \\
\hline Land holding (Hectare) & -0.042 & 0.131 & -0.33 \\
\hline $\begin{array}{l}\text { Availability of credit (Dummy measured as 1 } \\
\text { for easier to grant a loan compared to banks } \\
\text { and 0 for otherwise) }\end{array}$ & 0.425 & 0.485 & 0.88 \\
\hline Log likelihood & & & \\
\hline
\end{tabular}




\begin{tabular}{|l|l|}
\hline LR $_{\text {chi }}{ }^{2}$ & $108.06^{* * *}$ \\
\hline Pseudo $\mathrm{R}^{2}$ & 0.2580 \\
\hline Number of Observations & 350 \\
\hline
\end{tabular}

Note: $* * *$ Asterisk refers $1 \%$ level of significance respectively.

From our field surveys and findings, several problems related to the microfinance participation have been identified such as

- High interest rate of microcredit

- Those who earn low income, MFIs don’t provide large amount of loans.

- Those who are referenced by old borrowers, they can get loan early.

- Generally, allowable Loan repayment time is too short.

- Educated persons get loan easier than uneducated persons.

- Those who have no income MFIs don't give loan to them.

- DPS can be formed by the borrowers to get loan from MFIs. After opening DPS, they are forced/ propelled to withdraw loan from MFIs.

- Most of the time, borrowers expect as much as loan but they can't get the expected amount.

- The family which has no male income person, MFIs don't want to access female into microcredit

- Sometimes, the uneducated borrowers are fraud by field workers.

- Unmarried girls cannot allow getting loan by self-reference.

- Most of the time, MFIs collect their loan amount weekly basis.

\section{CONCLUSION AND RECOMMENDATION}

From the findings of this study it was clear that the participation in microfinance was recorded as a positive significant effect on the average income in its participants. This study also identified several factors which had negative effect on average household income and spouse' income was found as a key contributor on family income that could not be ignored. This study found that age, household size and other factors which had great influence on the decision of participants whether to adopt a loan or not. However several problems were recorded facing by the participants and arose by the system of microfinance whose overcoming might make microfinance closer to its goals.

This study suggests the following policies to better the management and credit policy of the microfinance.

- Reduction of interest rate of microcredit.

- Providing education loan at low interest rate.

- MFIs should provide the unemployed young people of the society with credit to make them self-employed.

- MFI should give the widows loan.

- MFIs should give loan to the unmarried girl to make them employed.

- Most of the borrowers want to repay their loan monthly basis.

- MFIs authority should supervise the field workers' activity and communicate the borrowers separately to avoid the chances of frauds.

- MFIs should increase the loan amount as well as loan repayment time to the low income borrowers. 
- Loan providing criteria should be minimized including educated persons with fewer deposits.

After having all of the above mentioned policies adoption, we can hope to have a better credit management of microfinance for the wellbeing's of general people and another well managed movement towards its goals.

\section{REFERENCES}

Al-Azzam, M. (2006). Essays on Group Lending: Evidence from Jordan. A Dissertation Submitted to the Graduate Faculty of the Louisiana State University and Agricultural and Mechanical College in partial fulfillment of the requirements for the degree of Doctor of Philosophy in Department of Economics, Louisiana.

Ariful, C. H., Atanu, D., \& Ashiqur, R. (2017). The effectiveness of micro-credit programmes focusing on household income, expenditure and savings: Evidence from Bangladesh. Journal of Competitiveness.

Basu, S., Roy, A., \& Karmokar, S. (2020). Effectiveness of microfinance on household income generation strategy in the southwest region of Bangladesh. Asian Journal of Social Sciences and Legal Studies, 2(3), 56-62.

Bhuiya, M. M. M. (2016). Impact of microfinance on health, education and income of rural households: evidence from Bangladesh (Doctoral dissertation, University of Southern Queensland).

Chowdhury, M. S. A., Arafat, A. Y., Islam, S., Akter, S., \& Islam, K. A. (2020). Impact of Rural Development Scheme of Islami Bank Bangladesh Limited (IBBL) Upon Economic Development of the Rural Poor of Bangladesh. The Millennium University Journal, 5(1), $1-14$.

Gujarati, D. N. (2009). Basic econometrics.Tata McGraw-Hill Education.

Hossain, M. K. (2012). Measuring the impact of BRAC microfinance operations: A case study of a village. International Business Research, 5(4), 112-123.

Imai, K. S., \& Azam, M. S. (2012). Does microfinance reduce poverty in Bangladesh? New evidence from household panel data. Journal of Development studies, 48(5), 633-653.

Islam, K. A. (2016). Rural Development Scheme: A Case Study on Islami Bank Bangladesh Limited. International Journal of Finance and Banking Research, 2(4), 129.

Jasmine, A. (2008). SHGs and Poverty Alleviation in Ramanathpuram District. Microfinance and Poverty Eradication-Indian and Global Experiences" New Century Publications, New Delhi, 569-580.

Khandker, S. R. (2005). Microfinance and poverty: Evidence using panel data from Bangladesh. The world bank economic review, 19(2), 263-286. 
Kondo, T., Orbeta Jr, A., Dingcong, C., \& Infantado, C. (2008). Impact of microfinance on rural households in the Philippines: A case study from the special evaluation study on the effects of microfinance operations on poor rural households and the status of women. Asian Development Bank, Manila.

Kundu, A. (2012). Can Microfinance Programme and NREGS Jointly Improve the Economic Condition of the Participating Rural Households? A Social Experiment. Asian Economic and Social Society, 2(2), 40-54.

Panda, D. K., \& Atibuddi, H. (2010). Impact of group-based microfinance on rural household income: evidence from an Indian State. Journal of Rural Cooperation, 38(886-201664633), 173-186.

Sarania, R. (2015) Impact Of Group-Based Microfinance On Rural Household Income: An Empirical Analysis.

Shahnaz, F., Rahman, G. S., \& Sadaf, B. H. (2018). Impact of Microfinance on Informal Employment: The Case of Bangladesh. Journal of Accounting, 8(3).

Sharma, H. R. (2008). Functioning and Impact of Microfinance: Evidence from Himachal Pradesh. In S. K. Bhaumik, Reforming Indian Agriculture: Towards Employment Generation and Poverty Reduction (pp. 269-290). New Delhi: Gage Publications.

Wright, G. A. (1999). The impact of microfinance services-increasing income or reducing poverty?. Small Enterprise Development, 10, 38-47.

Zewde, Z. N., \& Tollens, E. (2008). Microfinance Impact Evaluation at Household Level. In D. D. Lasar, \& P. P. Palanichami (Eds.), Microfinance and Poverty Eradication: Indian and Global Experience (pp. 294-320). New Delhi, India: New Century Publications.

\section{Copyrights}

Copyright for this article is retained by the author(s), with first publication rights granted to the journal. This is an open-access article distributed under the terms and conditions of the Creative Commons Attribution license (http://creativecommons.org/licenses/by/4.0/) 